\title{
Digital Library Platforms' Democracy Building Between Instrumental Education and Web 2.0 Sharing: A Swedish Case Study
}

\author{
Arwid Lund* and Pamela Schultz Nybacka** \\ *Södertörn University, Stockholm, Sweden, arwid.lund@sh.se (corresponding) \\ **Södertörn University, Stockholm, Sweden, pamela.schultz.nybacka@sh.se
}

\begin{abstract}
Digital platforms are a primary means of communication in society. Public libraries play an empowering role in these processes, strengthening citizens' digital competences. This raises questions about what democratic processes the digital technology is made to enable. The study investigates how a Swedish Digital Library (DL) is envisioned and organised within a national digitalisation strategy. Qualitative methods are used, and a theoretical democracy framework is developed and used together with the concepts of education and Bildung in the analysis. Four empirical themes are identified. The analysis centres on tensions related to horizontality and hierarchy, and Bildung and sociality. The DL vision is dominated by a hierarchical and instrumental educational vision that connects to representative democracy. A subordinated social and pedagogical vision of inner motivational drives and partial forms of sharing, connected to deliberative and semi-participatory democracy forms, exists, mostly in the form of some cherry-picked Web 2.0 discourses.
\end{abstract}

Keywords: digital libraries, regional libraries, digital platforms, Web 2.0, gamification, peer production, collaborative production, digital sharing, Bildung, direct democracy, participatory democracy, deliberative democracy, representative democracy

Acknowledgement: The research for this study has been financed by the Swedish National Library as part of the research project Digital First with the User in Focus.

\section{Introduction}

Fifty years after the birth of the Internet in the 1960s (Abbate 1999; Castells 2001), digitalisation is no longer considered an add-on or complement to societal institutions and public organisations. Digital tools, products and services are now expected to be a primary means of interaction and communication between citizens and the public sector. This development highlights the need for citizens to develop their digital competences and Media Information Literacy (MIL), a process in which public libraries may play an important part. It also raises questions about what kind of democratic processes digital technology enables and is made to enable. These questions are at the very core of the democracy-developing mission of libraries (Sundin and Rivano Eckerdal 2014; Rivano Eckerdal 2014).

The Swedish Library Law's portal paragraph requires that all aspects of library work converge in democracy development, but it is not clear what kind of democracy should be developed, except for a general aim of knowledge intermediation and free opinion formation for all (Bibliotekslag 2013, 801). Should this be achieved through top-down educational initiatives directed towards individuals? Or through bottom-up Bildung based on a user's own initiatives and practical participation, as individuals or groups, 
or even as communities? Different democratic forms answer these questions differently.

The study addresses the making of a Swedish national project for digitalisation centred around public libraries and librarian-led support for digital competence among Swedish citizens. A centrepiece of the project is the development of the digital platform Digiteket at the nexus of state, regional and local levels of the library sector. The central research question of this study concerns how this national project was envisioned and organised pedagogically and democratically by stakeholders at the various levels.

The article proceeds with a clarification of the case study's complex institutional context and a background section describing prior research into digital libraries. This paves the way for the third section on the article's research problem, aims and questions. The following section presents a theoretical understanding of the study's central concepts. This in turn is operationalised in a subsequent method section, which also discusses the collection and treatment of the empirical material. The sixth and main section presents the empirical findings from a close reading of the empirical material. Finally, the thematised empirical findings are analysed within the study's theoretical framework in a subsequent section and discussed in a concluding section that answers the research questions.

\subsection{The Case Study's Historical and Institutional Context}

The National Library of Sweden's organisation and administration is under the purview of the Ministry of Education and Research, while areas of readership and language development within libraries fall under the Ministry of Culture. On the one hand, regional libraries have a mission to support cultural and economic development, while there is no regional level of organisation for education and research. On the other hand, local public libraries and their librarians have an overarching mission to support democracy development.

The Swedish public library system was established in 1912 against the backdrop of industrialisation and the formation of capitalism. The founder, Valfrid Palmgren, nurtured ideas of, on the one hand, the role of libraries in the formation of democracy and Bildung for citizens, and on the other, the nation's need for well-educated human capital due to the increased competition within the world market. During this historic time, both of these concepts were accompanied by a desire to subordinate the working classes through a societal change firmly in the grip of the propertied class (Frenander 2012, 28). These two missions are recurring themes in the present-day digitalisation discourse, although the class dimension is less articulated.

In a global comparison, Sweden is one of the most digitalised countries in the world (Andersson et al. 2020; European Commission 2020), making Sweden an interesting case for research into the institutional settings of national digitalisation projects.

The Swedish government decided in 2015 that the public sector should be involved in and subjected to a large-scale digitalisation project, offering contact with citizens and companies primarily by means of digital services. This project was called "Digital First" (hereafter DF). The expressed aim was for Sweden to be the foremost country in the world in this area.

In 2017, the government assigned the National Library responsibility for a project targeted specifically at citizens in 2018-2020. The library project was named "Digital First with the User in Focus" (hereafter DFUF) (Uppdrag till Kungl Biblioteket om Digitalt Kompetenslyft 2017). The European Union's DigComp 2.0 framework for digital competence was applied in the project. 
In 2017, the government stated that the project would be the coordinated education (of digital competence) for public librarians in the country. DFUF was to aim to increase the digital competence of library staff, using regional organisations within the national library system as nodes for digital competence and development. The regional nodes would then mobilise the municipal libraries as hubs for the development of the public's competences (Uppdrag till Kungl Biblioteket om Digitalt Kompetenslyft 2017).

The DFUF project entailed three parallel tracks, involving the coordinators of the regional library organisations: 1) the Leadership track, for developing the role of regional librarians as leaders of the digitalisation processes; 2) the Legal track, which responded directly to the needs for greater competence in the area of digital law and security, and 3) the Sceptics' track, which supported critical discussions and reflections about both philosophical and practical experiences regarding aspects of digitalisation and digital competences within public libraries. Furthermore, the DFUF project also involved evaluative research in collaboration with academic institutions around the country: this includes the present study. The learning experiences within the DFUF tracks and research projects have subsequently been formed into learning materials for librarians.

One central part of the DFUF project was the establishment of a specific digital library platform and MIL project aimed at librarians in the Swedish public library sector. The platform was planned and set up between 2018 and 2020 and named Digiteket. It was developed in cooperation with Malmö Public Library (MPL) in the most populated city municipality in Sweden's southern region. MPL had experience from a previous digital project for sharing pedagogical resources among teachers. The EU's framework DigComp 2.0 (FPFIS 2016), with its focus on improving citizens' digital competences, was implemented in the development of Digiteket.

Following the spread of the coronavirus pandemic in March 2020, many societal functions, stakeholders and users (both citizens and companies) shifted to digital tools and services in line with the public recommendations. The DFUF project and Digiteket was thus set in a critical context.

To sum up the general organisational structure at this time: 


\begin{tabular}{|l|l|}
\hline Swedish National Library (SNL) & $\begin{array}{l}\text { Responsible for the Swedish library } \\
\text { sector. Placed under Swedish Ministry of } \\
\text { Education and Research. Appointed in } \\
2017 \text { by the government to head a } \\
\text { pedagogical digitalisation project in the } \\
\text { Swedish library sector. Later named } \\
\text { DFUF. }\end{array}$ \\
\hline Regional Libraries & $\begin{array}{l}\text { Principal mission: to promote public } \\
\text { libraries' cultural and economic develop- } \\
\text { ment work. Their role within DFUF was to } \\
\text { function as developing nodes. }\end{array}$ \\
\hline $\begin{array}{l}\text { Digital First with the User in Focus } \\
\text { (DFUF) }\end{array}$ & $\begin{array}{l}\text { A pedagogical digitalisation project that } \\
\text { the SNL led between 2018-2020. }\end{array}$ \\
\hline Digiteket & $\begin{array}{l}\text { Test pilot for a pedagogical, national, and } \\
\text { digital library platform. Developed within } \\
\text { DFUF. Central actors were the project } \\
\text { lead from SNL, a regional library co-ordi- } \\
\text { nator, and the editorial board including } \\
\text { pedagogical staff from the national library } \\
\text { and a public library in southern Sweden. }\end{array}$ \\
\hline DigComp 2.0 & $\begin{array}{l}\text { Digital Competence Framework for citi- } \\
\text { zens. The European Union's framework } \\
\text { for developing digital competencies } \\
\text { among its citizens. The framework was } \\
\text { applied in the development of Digiteket. }\end{array}$ \\
\hline
\end{tabular}

Table 1: Overview of the case study's context.

\section{Research Background}

Having positioned the study in its historical and institutional setting, we now move to a section dedicated to research into digital libraries from the 1990s to today. This paves the way for the introduction of the article's research problem, aims and questions.

\subsection{The Digital Library: From System to Something Social?}

The phenomenon of digital libraries (DL) can be understood as a field of research and professional practice, and as specific systems and services that are openly accessible on several levels (Calhoun 2014). Different scholarly perspectives have shaped the DL field since the 1990s (Borgman 2000, 35; 38). During the 1990s the computer sciences focused on DL as a technological system providing universal access, rather than on "institutions or objects of social influence" that permeated the library professionals' focus on the library users' needs (Jones 2017, 244). Early on, the 'digital library' concept was criticised for obscuring the relation between digital collections and the library as an institution (Lynch 1993).

Around the new millennium, the US professional Digital Library Federation (DLF) put forward one of the first definitions of DL from a librarian's perspective (Waters 1998). Further definitions delineate various types of DL. One kind of DL is the central archives that provide storage and deliver services from one single point, a second DL form distributes its content and services over multiple network locations that are federated, and a third type of DL aggregates the content of many other DLs (Calhoun 2014, 24). These different systems have varying relations to the library as institution. The 
relation between technological systems of potential global outreach and regional needs and design for different target groups include a broad array of tensions.

Calhoun contends that the digital transformation of libraries has generated a shift away from a focus on (digital) collections and towards their social role of building communities as facilitators of conversations - a paradigmatic change $(2014,140)$. The 'Web 2.0' or social web discussion has slowly made inroads in a digital library context traditionally characterised by higher technical and organisational thresholds. Web 2.0 advocates propose the development of community-centric platforms rather than collection-centric ones (Calhoun 2014); that is, they advocate platforms that invite and evoke user interactions for commercial reasons (Lund and Zukerfeld 2020).

Calhoun breaks down the social roles of DLs in relation to community benefits in a way that indicates a tension between the social and the individual. DLs support selfeducation and self-improvement, increasing the individual's knowledge about social, political and community issues. The individual is in focus even when the social is addressed. DLs also have a focus on the formal education of users (Calhoun 2014, 146147), rather than on Bildung.

\subsection{The Digital Library User: Generic or Socially Conditioned?}

There is a tension in the DL field's discourses between a generic and cognitive view of the user and a view of the user as socially conditioned. Computer scientists initially worked within a system paradigm with visions of a singular universal DL with a focus on access (Bearman 2007), whereas professional librarians adapted (and developed) technology in line with institutional and target group needs (Jones 2017). The latter perspective is taken up within a processual micro-sociological perspective. Here, the $\mathrm{DL}$ is understood as a part of interactions between networks of technology, information and documents, and people and their practices, often within communities of practices. This perspective claims to connect DLs to the world of work, production of knowledge, other institutions and society (Bishop et al. 2003, 1; 9; Lave and Wenger 1991).

DLs are often developed for specific user groups composed of adults with professional information needs and access to high-speed networks (Bearman 2007). However, access to DLs is not only a technological issue but also a cognitive and social issue (Bishop et al. 2003), and user groups differ in their activities. Contemporary digital platform users often take the role of producers. New concepts such as prosumers, produsers, contribusers, and peer producers (Benkler 2006; Lund 2015b; 2017; Lund and Zukerfeld 2020) reflect this development.

\section{Problem, Aims and Research Questions}

This section, building on the cited earlier research and contextual environment, presents the article's research problem, aims and questions.

\subsection{Research Problem}

Public projects at all levels of society (international, national, regional and local) are tied to different institutional and political conditions and missions, ranging from education, research, economic growth and innovation to issues of culture and democracy. Public administration in Sweden contains an inherent tension between state-level government and the relative autonomy of regions and municipalities (Bengtsson and Melke 2019, 129; 132). This complicated institutional setup makes for a variety of focuses and creates a field of tensions that have not been widely researched in a Swedish library context. 
With DFUF, the library sector is expected to operate at the nexus of society while remaining at the forefront of digital development. This applies specifically to the role of Digiteket, a national DL involving the regional library organisation tasked with the professional development and training of local public librarians. As a pedagogical tool for digital competences, Digiteket functions as a focal point for how the library sector envisions its mission regarding democracy and global competitiveness in relation to increasingly pervasive digital ICTs. This study scrutinises Digiteket's approach with regard to democracy .

Previous research has observed a high level of trust in Digiteket among regional library professionals, giving rise to the reflection that Digiteket may just be providing the "coordinating education for the country's public librarians", that was hoped for from the entire DFUF project (Lindberg et al. 2020). This study will instead focus on the pedagogical views, sociality and democratic visions expressed on and about the platform within DFUF.

\subsection{Aims and Objective}

The research aims to explore and scrutinise the role of the DL platform and MIL project Digiteket, and its construct, organisation and processes, within the context of a national strategy for digitalisation and the DFUF project. The objective of the study is to shed light on which democratic visions in particular inform the development of a nationally, regionally and locally managed library platform aimed at fostering digital competences on a local public library level.

\subsection{Research Questions}

The main research question of this study is as follows: How is a national digitalisation project in the library sector envisioned and organised pedagogically and democratically by means of a digital library at the nexus of state, regional and local levels?

This research question can be broken down into two more specific questions:

1. What kinds of social interactions and pedagogical strategies do Digiteket's project developers favour among users and produsers? ${ }^{1}$

2. What democratic visions do Digiteket's project developers favour in the development of digital competences on the digital platform?

\section{Theory}

The previous section introduced themes such as democracy and pedagogy. These themes are theory-laden. This section presents a theoretical understanding of central concepts relating to these themes: concepts that are used in the study's analysis section. Various democracy forms and theories are first presented and compared. The complex democracy concept is further operationalised in Table 2 in the subsequent method section. The concepts of Bildung, education and gamification are thereafter defined.

\subsection{Democracy Forms}

Democracy is a central concept within the political sciences. This study's theoretical understanding of the concept is not comprehensive, and only strives to present a general framework of democratic visions that span the spectrum between two principal democratic positions in Western society: liberal representative democracy and

\footnotetext{
${ }^{1}$ Produser is a concept defined by Lund and Zukerfeld (2020) as a producer-user.
} 
Athenian direct democracy (Grugel and Bishop 2013, 22-23). Intermediary positions in the spectrum include participatory and deliberative democracy (Dryzek 2000; Gutmann and Thompson 2004; Pateman 1970; 2012).

Direct democracy draws on the notion of a popular government, originally within a Greek or renaissance republican city-state. The concept has since been used in relation to notions of economic democracy. Rousseau even argued for an unmediated popular government where citizens themselves decide laws and policies. The tradition is in general concerned with "ensuring democratic rights for the community as a whole" (Grugel and Bishop 2013, 22). David Held first points out political equality, direct participation and the sovereign power of the citizens' assembly in relation to Athens' classical democracy, but later connects direct democracy to socialism and communism, and the self-regulated end of politics (2006).

Representative democracy, by contrast, draws on the notion of individual rights, including voting rights, but with no obligations to participate in politics (Grugel and Bishop 2013, 23; Hansson 1992, 9). Advocates of a 'realistic' democratic position stress that not all citizens have an active interest in politics (Pateman 2012, 7). The people's sovereignty is vested in representatives who exercise state functions, and the state and civil society are separated from each other. Representatives come from competing factions and are elected in regular elections (Held 2006).

During and after the 1960s revival of critical theory, theoretical attempts were made to "go beyond liberalism or representative democracy through participation or communitarianism" (Grugel and Bishop 2013, 36). Advocates of participatory democracy in the 1960s had an "active citizenry at its center" (Pateman 2012, 7). Participatory democracy contends that voting rights and alternation in government is not sufficient for democracy to exist. The development of democracy is achieved by "deepening reciprocal relations of trust between individuals", and this democracy extends to the workplace (Grugel and Bishop 2013, 36-37), as Carol Pateman showed in a seminal work in 1970. Pateman connected participatory democracy to guild socialism, but also to the example of workers' self-management in former Yugoslavia (1970). ${ }^{2}$

In revisiting the theme in 2012, Pateman notes that democratic theory has had a revival and that the term 'democracy' today is qualified by a series of adjectives, of which deliberative democracy is the most popular. The core of this position is that "individuals should always be prepared to defend their moral and political arguments and claims with reason, and be prepared to deliberate with others about the reason they provide" (Pateman 2012). Deliberation is a distinctive social process in which the deliberators are "amenable to changing their judgements, preferences, and views during the course or their interactions, which involve persuasion rather than coercion, manipulation and deception" (Dryzek 2000, 1). Value pluralism, together with democratic methods and infrastructures like polls, fora (online or otherwise), citizen juries, and egovernment's direct access to representatives are characteristic of this form of democracy (Held 2006).

Deliberative democracy is the conceptual successor of participatory democracy. The former is a type of participation, but in a narrower sense than the original concept (Pateman 2012, 8). Deliberative democracy's focus on ideas and rational discussion, in contrast to participatory democracy's more sociological position, comes close to

\footnotetext{
${ }^{2}$ There are various socialist strands that assert this idea of a participatory democracy in industry and the workplace. Juxtaposed to guild socialism, we have revolutionary syndicalism/anarcho-syndicalism and council communism (Lund 2001; Wikipedia contributors 2021). But these positions, at least in their original form, can better be categorised as direct democracy in the way Held suggests.
} 
liberalism. Gutmann and Thompson define it as affirming "the need to justify decisions made by citizens and their representatives" $(2004,3)$. But here differences in relation to liberalism are also found. Dryzek contends that liberalism at its core is based on self-interested individuals rather than on the common good, and that individuals are "the best judges of what this self-interest entails" $(2000,9)$. Deliberative democracy, in contrast, emphasises the persuasion and changing of opinions through deliberation, and the critique of established power structures, whereas traditional liberal representative democracy "deals only in the reconciliation and aggregation of preferences defined prior to political interaction" $(2000,2 ; 10)$.

\subsection{Bildung and Education: a Conceptual Distinction}

Bildung is a German word with two etymological roots: bildunge and bildunga (Wiktionary contributors 2019). Olsson Dahlquist asserts that the word contains two meanings: to build and form something in a free learning process that cannot be imposed on the learner, and the result of that process, understood in terms of societal or social aspirations. She connects the first free process to a self-Bildung ideal (självbildningsideal). The effect or goal is not the important factor for this ideal. Instead, the knowledge in itself has a value (Olsson Dahlquist 2019, 32-33).

Bohlin (2018) in turn makes a distinction between two instrumental forms of education in relation to higher university education: a narrower economic one and a broader social one that incorporates Bildung. He contends that today's market ideal for higher education is to prepare students for a profession by building their employability. At the same time, an understanding of society as community that shares a common goal of greater good lingers. Higher education in the latter tradition is not only about preparing for employment in a profession but includes developing Bildung in order to be a citizen and solving problems for the benefit of society (Bohlin 2018, 9; 60).

The two concepts handle the tension between learning process and outcome differently. Education always has an instrumental logic but can be infused with Bildung in some instances. The Bildung that is integrated in education inherits some instrumental logic from education.

\subsection{Gamification and "Sharification"}

Zichermann and Cunningham (2011) describe gamification as a popular Web 2.0 technique. The concept has since gained traction in various scientific disciplines and among business professionals (Seaborn and Fels 2015). The concept has, for example, been tied to service marketing theory in pointing out its support of users' "overall value creation" (Huotari and Hamari 2017, 25) by using non-monetary and intrinsic gratifications (Morschheuser et al. 2019). The concept's manipulative use of intrinsic motivations in non-game contexts has been addressed from an ethical standpoint, but in an instrumental way: prescribing transparency in its implementation (Marczewski 2017). This unproblematised intermixing of external and intrinsic motivations has met with radical critique. Making a crucial distinction between playing and gaming, Lund contends that gaming (and gamification) introduce an instrumental and exploitive capitalist logic into playing that (by definition) is non-instrumental and joyful (Lund 2015a; 2015b; 2017).

The concept of sharification used on Digiteket is modelled on the gamification concept and relates to notions of a sharing economy that is often portrayed in ideologically deceitful ways (Lund and Zukerfeld 2020). Here, in contrast, the concept is used in the management of a non-commercial digital library. 


\section{Method}

The study is conducted as a qualitative case study. The case in focus is regarded as a specific example of a broader societal phenomenon open to observation, interpretive exploration and critical scrutiny. The first part of the section discusses the collection of the empirical material. The second part presents the preliminary treatment and thematic analysis of the material. And the third part presents an operationalisation of the concept of democracy presented in the prior theory section. Section 5.3 aims to provide an interpretative tool for a separate and deeper analysis of the empirical material.

\subsection{Presentation of Empirical Material and Collection Methods}

The empirical materials used in this case study are semi-structured interviews, continuous meetings with the project lead, a digital project presentation, project policy guides for content production, and the design and content of the platform.

The interviews were conducted with project members in DFUF (names are pseudonymised): the project lead Karin, the regional coordinator Anna, and the editorial team, consisting of Lars, employed by the National Library, and Erik and Anders, employed by Malmö Public Library. Lars and Anna were interviewed on October 20, 2020 (interview 1), Erik and Anders on November 13, 2020, (interview 2), and Karin and Anna on November 30, 2020 (interview 3). All three interviews were conducted on Zoom and transcribed mostly verbatim, with minor and less relevant passages being transcribed more selectively. The continuous meetings were held with the project lead during spring 2021 (Karin and Anna, January 25, 2021; February 8, 2021; April 13, 2021). These meetings were used for follow-up questions.

The policy guides for the creation of articles and courses on Digiteket were handed over to the authors by the informant Lars. Field notes and screenshots were collected from a digital project presentation held by Lars, Erik and Karin for students at Södertörn University's Library program.

Digiteket's design and content are used as empirical material in several ways that complement the views expressed in the interviews and policy guides. This empirical material has an auxiliary function. The design and content of the platform were investigated when they added to the identified themes in the rest of the material. The design was investigated by scrutinising features of the web page. Six articles have been scrutinised in relation to how they are produced or in relation to the themes that they address (the platforms group function and the introduction to the concepts 'sharification' and 'gamification'). Courses are only examined in relation to their main creators.

\subsection{Thematic Results Presentation}

The empirical material, transcriptions, policy documents and the presentation were first thematised in a preliminary analysis. This first round of analysis consisted of a close reading of the transcriptions of the interviews, the guides, and notes from the student presentation, followed by identifying and coding themes at the text level that connect to the research questions. In the second round of analysis, the various texts were reread and the several identified themes from the first round were merged under an already existing label, or under a new one. Sometimes the label was slightly revised. In a third and final round of analysis, some themes that did not gather enough empirical material were merged with other adjacent themes, others were omitted entirely as they were included in other themes, and some were, finally, renamed. Two themes, commerciality and copyright, were removed for a separate article. Four themes remained for analysis: Artifact, Teaching and learning, Sharing, and Social production processes. 


\subsection{Analysis Method}

This section presents a table that operationalises the democratic forms that were introduced in Section 4. The table will be used as an analytical and interpretative tool in the study.

\begin{tabular}{|c|c|c|c|c|}
\hline & $\begin{array}{l}\text { Direct } \\
\text { democracy }\end{array}$ & $\begin{array}{l}\text { Participatory } \\
\text { democracy }\end{array}$ & $\begin{array}{l}\text { Deliberative } \\
\text { democracy }\end{array}$ & $\begin{array}{l}\text { Representative } \\
\text { democracy }\end{array}$ \\
\hline Aim & $\begin{array}{l}\text { Democratic } \\
\text { decisions } \\
\text { taken by a } \\
\text { community as } \\
\text { a whole }\end{array}$ & $\begin{array}{l}\text { Active } \\
\text { participation in } \\
\text { the decision } \\
\text { process by } \\
\text { communities or } \\
\text { (in various } \\
\text { forms) people } \\
\text { affected by a } \\
\text { decision }\end{array}$ & $\begin{array}{l}\text { Rational and } \\
\text { idea-based } \\
\text { discussions of } \\
\text { individuals', } \\
\text { groups', or } \\
\text { representatives' } \\
\text { decisions }\end{array}$ & $\begin{array}{l}\text { Individual } \\
\text { citizens, ideally } \\
\text { well-informed, } \\
\text { vote for } \\
\text { parliamentary } \\
\text { political parties } \\
\text { and } \\
\text { representatives } \\
\text { that take } \\
\text { democratic } \\
\text { decisions for all } \\
\text { citizens }\end{array}$ \\
\hline $\begin{array}{l}\text { Time } \\
\text { dimension }\end{array}$ & $\begin{array}{l}\text { Part of the } \\
\text { decisions }\end{array}$ & $\begin{array}{l}\text { Part of the } \\
\text { decisions }\end{array}$ & $\begin{array}{l}\text { About a } \\
\text { decision }\end{array}$ & $\begin{array}{l}\text { Future } \\
\text { decisions }\end{array}$ \\
\hline $\begin{array}{l}\text { Major form } \\
\text { of process }\end{array}$ & $\begin{array}{l}\text { Horizontal } \\
\text { social } \\
\text { practices - } \\
\text { discursive } \\
\text { and embodied } \\
\text { interactions - } \\
\text { between } \\
\text { peers in a } \\
\text { general } \\
\text { assembly that } \\
\text { takes } \\
\text { decisions }\end{array}$ & $\begin{array}{l}\text { A mixture of } \\
\text { reciprocal social } \\
\text { practices - } \\
\text { discursive and } \\
\text { embodied } \\
\text { interactions - } \\
\text { and semi- } \\
\text { hierarchies } \\
\text { (representatives } \\
\text { exist). The } \\
\text { semi- } \\
\text { hierarchical } \\
\text { relation behind } \\
\text { a decision vary }\end{array}$ & $\begin{array}{l}\text { Horizontal } \\
\text { discursive } \\
\text { practices in the } \\
\text { form of social } \\
\text { dialogue and } \\
\text { critique for the } \\
\text { common good }\end{array}$ & $\begin{array}{l}\text { Highly } \\
\text { regulated and } \\
\text { hierarchical } \\
\text { standards for } \\
\text { discursive } \\
\text { interactions } \\
\text { between } \\
\text { individual } \\
\text { citizens and } \\
\text { political parties, } \\
\text { or } \\
\text { parliamentary } \\
\text { representatives }\end{array}$ \\
\hline $\begin{array}{l}\text { Actors in } \\
\text { decision } \\
\text { making }\end{array}$ & $\begin{array}{l}\text { Citizens/peers } \\
\text { (collectives) }\end{array}$ & $\begin{array}{l}\text { Participants } \\
\text { (collectives) } \\
\text { and } \\
\text { representatives. } \\
\text { Reciprocal } \\
\text { relations are } \\
\text { dominant }\end{array}$ & $\begin{array}{l}\text { Groups of } \\
\text { citizens/peers, } \\
\text { (sometimes } \\
\text { discussions of } \\
\text { representation } \\
\text { and } \\
\text { representatives' } \\
\text { decisions) }\end{array}$ & $\begin{array}{l}\text { Individuals, } \\
\text { political parties } \\
\text { and } \\
\text { parliamentary } \\
\text { representatives. } \\
\text { Political parties } \\
\text { and } \\
\text { representatives } \\
\text { are dominant }\end{array}$ \\
\hline
\end{tabular}

Table 2: Operationalisation of theoretical positions on democracy in Section 4.

Together with this table, the concepts of Bildung, education and gamification, as defined in Section 4, are used as theoretical lenses for analytical purposes. 


\section{Empirical Findings}

Following the presentation of the introductory, theoretical and methodological groundwork, we now present the empirical findings from a close reading of the empirical material. The identified empirical themes that will be brought to bear on the study's research questions are: Artifact, Teaching and learning, Sharing, and Social production processes. The various parts of the empirical material - documents, interviews, and presentations - will be referred to with the following abbreviated name forms:

Article guide: (AG)

Course guide: $(C G)$

Interview 1 with Lars and Anna: (I1)

Interview 2 with Erik and Anders: (I2)

Interview 3 with Karin and Anna: (I3)

Presentation for students at Södertörn University by Lars, Erik and Karin: $(\mathrm{P})$

Informants' first names will be included in reference when needed for clarity. Finally, references to the digital platform itself and the regular meetings with Karin and Anna during the spring of 2021 will be referred to in line with standard reference notation. All quotes are translations from Swedish by the authors.

The themes detected in the close reading differed depending on the source of the empirical material. The two guides did not contain as much material on the social production process as the interviews. The guides belong to a specific, instrumentally encoded genre, with greater focus on the 'how to', and in this case in relation to the creation of articles and courses on Digiteket. The theme Artifact is fairly dominant in these sources, and in relation to the information derived from the platform itself (AG; CG; Kungliga biblioteket 2020). It is telling that the guides do not focus at all on the 'how to' of cooperation or collaboration in the production of pedagogical content (AG; $\mathrm{CG}$ ). Finally, the theme Social production processes is mainly activated in the interviews $(11 ; 12)$, prompted by the researchers' questions.

\subsection{Artifact}

This theme follows two dimensions. One concerns the design features of the platform, the other the ways in which guide manuals portray the artifact character of the platform's articles and courses.

Digiteket's platform consists of articles and courses that are derived thematically from the EU's DigComp 2.0 framework. Five themes have been extracted and adapted from the framework: information and analysis, digital collaboration, creating content, security, and problem solving. The themes structure the platform's design and connect to a self-evaluation test for individual users. The platform also has a group function consisting mainly of an online chat function (Krämer 2020d; Kungliga biblioteket 2020; $11 ; \mid 2)$.

DFUF's identification of five core digital competences have a strong influence on the design and organisation of platform content (Kungliga biblioteket 2020). The setup emphasises themes related to individual competences. Anna and Lars remark that this is problematic, as there is a need to shoehorn in new themes connected to organisational development that do not align naturally with the DigComp scheme (I1). Anna wants to add a sixth mixed category for institutional and professional themes such as service design, leadership, method development, and organisational development (I1). These competences are more social in character. 
The platform's group function also aims to introduce social interaction (I1). In late August 2020, it was updated with clarified features. It now has a tab in the horizontal top menu, juxtaposed to the tabs of the articles and courses. The user can choose between All groups, My groups, Groups I have created, and finally the function of Creating a new group. The option of public groups was also added. (Krämer 2020d; Kungliga biblioteket 2020). The initial group function was more rudimentary. It contained only private groups, a simple chat, no digital working areas, and no uploading and sharing of files $(11 ; 12)$.

According to Anna, project members and Digiteket's users had already expressed a wish for an improved group function at the project's outset (I1). Users could not search for and find other users' groups: these were all private and the user had to be invited to them. These initial design choices were made early in the project before the editorial board had begun operations (I1). Erik says the main aim was to avoid technological and functional complexity on the platform (I2), whereas project lead Karin stresses practical and administrative reasons behind the choices (I3).

The view of the digital as something complex and difficult is reflected in the platform slogan "Digiteket: your guide in the digital jungle" (Digiteket 2020). The digital is also visually portrayed as something wild and slightly intimidating. This jungle theme differs from statements regarding public librarians' prolific use of social media (I1). Lars mentions that "we are spoiled with functions like these [Facebook] that can do so much more" (I1). Anna tells us it is hard to get conversations going between librarians on platforms other than Facebook (I1). This familiarity with digital social media's many social functions has not been acted on in the design of the platform.

The personal pages for registered users were updated and personalised in the 2020 revision. An option to upload profile photos bore the social aim of making the identification of group participants easier, but the remaining personalisation was individually focused on the gamification of the user experience, such as presentation of personal statistics from the self-evaluation test and visualisations of personal progression in completing courses within the five DigComp areas (Krämer 2020d; Kungliga biblioteket 2020). Still, links exist between the visualisation of the personal page and the group function. An award section - a subset of the statistic display of the personal page - registers and awards socially directed activities like creating groups, library networks, commenting, and teamwork. Individual achievements are presented with slogans like "A proof of your curiosity. Can you manage to reach the top?", whereas the group-related activities are promoted explicitly by the sender: "We like that you build team[s]. The more the merrier", "Work across the borders! You will receive these awards when you create groups with colleagues across the country", "Communicate more! You will receive these awards when you make your first comment in a group", and finally "You will receive this award when you have completed all joint courses in a group. High five!" (Kungliga biblioteket 2020).

The Artifact theme is also articulated in guide manuals that mostly portray the platform's content in reified terms. The article guide explains the differences between articles and courses. Articles shed light on activities and present research, courses teach skills and give technological insights; both categories may contain text, video and audio parts (AG). Of eleven pieces of advice to an individual creator on how to improve an article, ten focus on artifact aspects, and only one concerns social processes and aspects (AG). The course guide, for its part, sees Digiteket as a "knowledge bank", aiming to achieve "uniformity in the design of the courses" (CG). The focus is on packaging "all the expertise you hold so that it reaches the users in an easy-to-handle, well-structured and pedagogical way" (CG). Everyone should be able to "recognise themselves 
in the course structure" that should be concrete with a clear sense of the course's target group (CG). The editorial team also classifies and marks each course with an appropriate level of expertise (CG).

\subsection{Teaching and Learning}

The platform is presented as a "guide in the digital world" to its users and 4,700 registered members, who are mostly public librarians, except for 200 coming from the school environment (CG; P). Its courses are presented as a "knowledge bank" of storable learning resources, connected to the EU's Digital Competence Framework for Citizens' necessary skills and competences (CG).

The bank concept is articulated with an emphasis on standardised and professionally designed and well-structured courses that are easy to handle (CG). The guide itself is said to contain examples of "good pedagogy" - a kind of benchmark reification focused on making "difficult material accessible in an easy way" within an "uncomplicated pedagogical structure" (CG).

This overall instrumental perspective can be connected to the government's assignment description for DFUF, and to the demands of librarians. First, the government emphasises: "competitive power, full employment, and economically, socially and environmentally sustainable development" (Uppdrag till Kungl Biblioteket Om Digitalt Kompetenslyft 2017). The instrumental pedagogy is here aligned to global competitiveness. Second, the librarians, according to Karin and Anna, want to know the right way to do digital things. Therefore, the people involved in Digiteket also want to teach what is correct (Karin and Anna, 25 January 2021). ${ }^{3}$ However, the Sceptic track (Skeptikerspåret), a research group related to DFUF, suggests that the Swedish state does not have an established tradition of educating citizens with DigComp's top-down approach in the library sector, with its focus on education rather than on Bildung (I3). This acknowledgment makes DFUF's historic choice of the framework even more significant.

Could it then be said that Digiteket and DFUF prioritise instrumental education? Erik and Anders repeatedly talk about continuing education (fortbildning). Fortbildning has direction but is also open-ended, continuous and ongoing. Anders states clearly that Digiteket is goal-oriented: "[Digiteket] relates to DigComp's 40 points [...] every course starts with what you should learn" by doing the course (I2). To him, Bildung is something else, something broader, that connects to important values in society that cannot really be evaluated. Digiteket is something else:

[I]f we talk [...] best in the digital class and so on, it is very goal oriented. It is very clear, we should be best because it is good for GDP, and it is a competitive advantage with the EU and so on. The EU's formulations are also a lot of 'we should be best because we compete with the US, Russia and Asia'. (Anders I2)

Digiteket's regional co-ordinator, Anna, defends the self-evaluation test and DigComp as a base for personalising the platform's recommendations of teaching material: "this absolutely creates motivation to continuous learning" (Anna I1). The framework has also been important in clarifying and analytically breaking down the concept of competence (Anna I3).

${ }^{3}$ Chat comments from regional librarians also indicate uses of the platform that align with the 'bank' concept. One librarian even writes: "There it all is, and it is all quality assured" (Svedgård Lindmark, 2020b). 
But freer forms of Bildung are not totally out of the picture. There is a desire within the project for learners to practice "self-study" with no attached examination mechanisms (CG). Digiteket as a site for continuing education is dependent on the "user's own will to learn, there are no control mechanisms" with no external incentives and "no way for the employer to control and extract statistics to see to what degree the employees are continually educating themselves" (Erik 12). This argument comes close to the concept of Bildung as a free process. Internal motives and drives are emphasised in contrast to external control and goals.

Lars, on the other hand, mentions that completed courses on the platform, made visible by gamifying statistics and diplomas, will be discussed by library managers in the traditional performance assessments with the staff $(P)$. And Anna mentions that public librarians have been mandated to take specific courses in relation to the regional libraries' educating activities (Karin and Anna, 25 January 2021).

The self-study processes are sometimes understood to be both individual and social within the project. For example, the use of control questions in the courses are directed to individual learners but should, according to the course guide, try to build bridges to the learner's personal experiences and context. Control questions should be followed by recommendations for the user to discuss those questions with colleagues - explicitly colleagues at work and, less explicitly, colleagues in other municipalities (which would mean studying together on the platform) - to deepen the insights being made (CG). So, although the self-study perspective in the course guide is tilted toward the individual rather than the social study group, social forms of studying exist in the guide.

\subsection{Sharing}

Social dimensions can also be noted in the strong presence of the sharing trope "sharing thought" or "sharing culture" - in relation to the reified learning resources in the "knowledge bank" (I1; I2; CG; Kungliga biblioteket 2020). This form of sharing has its own properties. The sender and receiver of the learning resource are not particularly connected to each other (I1; CG). Receivers are described mainly as "readers" in the article guide (AG).

Most often, ambitions and reality contrast with each other in relation to social learning. Digiteket recommends users to "study on your own or together with colleagues in your own work place, or in other municipalities" (CG); or to build teams and communicate more under the motto "the more the merrier" (Kungliga biblioteket 2020), but the rudimentarily developed group function - initially not advocated actively by the editorial team $(I 1 ; \mathrm{I} 2)$ - made social interaction difficult between librarians who did not know each other.

The sharing in the case of Digiteket mostly takes the form of shared learning resources. The "sharing thought" and "sharing culture" (Lars I1; I2) are never expressed in terms of sharing resources outside Digiteket, on other platforms. This differs from the norm of facilitating spreadable media within the sharing industry and Web 2.0 discourses (Jenkins et al. 2013), but gamification does exist on Digiteket. This popular Web 2.0 technique (Zichermann and Cunningham 2011) connects to sharing. On Digiteket the editorial team has invented the word "sharification" ("delifiering") to connect the concepts even more tightly (Krämer 2020e).

Gamification is used by Digiteket's editorial team in various ways. Statistics form its central element. Activities on the platform become registered data that mediate changes in the user's status, for example from Newbie to Adventurer. Gamification is explained as the method used to achieve the goal of sharification (Krämer 2020e). 
Gamification, it is explained, uses rules and internal/external motivations to change behaviours. It contains design features such as merit badges, quests, top lists and collectibles, and tries to activate people's desire for social distinction (status) and internal rewards. Digiteket's gamification centres on avatars, various levels of engagement and merit badges (Krämer 2020e). It can be seen in the award section of the personal profile pages (Kungliga biblioteket 2020), although the editorial team admits that the gamification elements are few and have not yet reached their purpose and function. The platform is at an early phase, but the editors think the time is ripe for deepened forms of gamification on Digiteket to get users "involved and learning at the same time" (Krämer 2020e). Gamification could in turn help to trigger positive feedback loops from peers, motivating people to start sharing (Erik I2).

Gamification is here used to stimulate the social act of sharing in the same way as in the commercial Web 2.0 setup, but the main instrumental rationale is different: learning and not profit is at the centre of attention. Lars (I1) states: "[I]f you make a course on [a] very local level, you should think [...] this could come in handy for others as well". The goal of sharing is mainly to make the education effort more effective (Anna I1; Erik I2): to build more digital competences for less money (Erik I2), and to avoid repeatedly reinventing the wheel (Anna I1).

Another difference from the more established social media platforms is the realisation of how difficult it is to "sharify" or evoke sharing (Erik 12). Anna states that "[i]t is extremely difficult to start discussions and conversations on platforms, especially if the platform is something other than Facebook" (I1). In future, the library sector will have to mature in its communication on digital platforms, seeking conversations more actively instead of waiting for email notifications (Anna I1). Gamification is thus needed (Krämer 2020e), yet does not seem to be enough to encourage sharing on the platform.

There are two reason why sharing is problematic. First and foremost, Digiteket is a venue for professional interactions and continuous education - serious activities connected to wage labour (I2). The users are public librarians, and the competences are ultimately locked on the state's need for increased global competitiveness. Professionality and the quest for global competitiveness thus counteract sharing on the platform. This said, the "sharing thought" that has been present all along in the project (Lars I1) is not an unqualified form of sharing. The sharing needs to align with the platform's aim. Individual librarians cannot share whatever they want, even if it is an important goal to get individual librarians sharing resources with each other (Anders 12). Anna even states that sharing is a "super important" competence within the professional role of librarians (I1). This leaves us with a paradox. Because of professional formality the sharing fails to materialise, yet the advocated sharing is required to be professional and formal. Sharing is both an end itself and a means to another, contradictory, end. Secondly, the initiation of sharing is also problematic in the light of new legislation regarding web accessibility for people with, for example, visual impairments. Anna points out that web accessibility takes up large parts of both the article and course guide, and it makes the production and sharing of learning resources more difficult (Karin and Anna 13 April 2021).

Ideally, though, Anders would like to abolish the editor as a producer and sharer of learning resources (I2), whereas Erik stresses the need for a new, more horizontal governance model - if a Wikipedian production model were to be applied (I2). Anders, for his part, believes that editorial top-down decisions are needed for now (I2).

Tensions are thus detected in the project's view of sharing. In relation to these tensions it is interesting that no explicit distinctions are being made by the informants between sharing resources and sharing work practices on the platform (I1; $12 ; 13)$. 


\subsection{Social Production Processes}

This section opens with some observations and statements concerning social production processes, listed as follows: 1) In the scheme derived from DigComp's framework, digital collaboration is singled out and separated from content creation and production (Kungliga biblioteket 2020). 2) The self-evaluation test lacks focus on digital competences in relation to the development of organisational operations (I1; Anna I3). 3) Despite the self-evaluation test's individual focus, the test has helped regional libraries to identify locally needed competences and to conduct working group discussions, and occasionally even to jointly produce learning resources for the platform (I1; I3; Karin and Anna, 8 February 2021). ${ }^{4} 4$ ) The course guide recommends a feature called challenges which can help spread learned knowledge "in the workplace" with the aim of achieving "actual concrete change in the operations" (CG). 5) The article guide advises users to let someone else read through their article before submitting it to the platform (AG). From these five statements, it is implied that social production processes are or should be going on elsewhere, typically in the library, rather than on the platform.

Often the statements about sharing are quite general $(I 1 ; 12)$. The informants do not explicitly distinguish between the dominant view of sharing locally and individually produced resources (or ideas in the learning process) on Digiteket, and the sharing of social work activities (I1). The social production process on the platform comes only close to being explicit once. Erik contends that the goal is to attain a sharing culture which does not result in "a technocratic 'We do the things for you!', but in 'How we do things together"' (I2).

Production could potentially be included in the concept of 'doing'. If so, the sharing of production processes would be seen both as a goal and a means for a successful project. Such a position contrasts with the design of the platform and the rudimentary group function, which lacks social workspaces and functions for sharing files $(11 ; \mathrm{I} 2)$.

Overall, social production processes are not prioritised on the platform. Erik recalls the early discussions about platform design and the lack of social workspaces. Project members said it was "too complicated" (I2) and that such technologies would make it harder to involve - and would raise the thresholds for - the platform's target group $(P)$. It was better to buy already existing commercial systems, if workspaces were to be used (Erik 12). The reason behind this position was the fear of passing over the target group of the platform: the public librarians (Erik I2). This is a target group that Anna, Karin and Lars contend is less accustomed than teachers are to sharing and producing resources digitally as pedagogues, although its members are knowledgeable about social media $(11$; I3). Karin, the project lead, remembers the project's beginnings differently. She initially wanted to have a platform with shared working spaces, but this changed when MPL - already a partner to the National library - was chosen to develop the platform. Their platform concept was developed by an external software developer that wanted to scale down the design, and it was important to keep MPL as a partner. It takes time to procure a new service provider, and an ideal one would continue to curate the platform after the project was finalised - as MPL would. Karin did not want the prototype to end up as a "skeleton in the closet" (I3; Karin and Anna, 8 February 2021). Regardless of the tension in these statements, social production on the platform was not prioritised in its design.

${ }^{4}$ The theme of leadership, security and infrastructure is also part of the governmental strategy behind the project. A strategy that was quite new when the project started (Regeringen et al. 2017; I3). 
Some minor forms of social cooperation do occur between the editorial board, regional libraries, public librarians and other actors. During the first outbreak of the coronavirus pandemic in March 2020, the extreme situation led to the publication of three interesting articles under the hashtag \#Digitalabiblioteket: these were Digital folkbildning (Digital Bildung for the People), Digitalt läsfrämjande (Digital Reading Promotion), and Digitala mötesplatser (Digital Meeting Places) (Krämer 2020a; 2020c; 2020b; Svedgård Lindmark 2020a). These articles were updated continuously by the editorial board, which added local public library news relating to the three themes. It was the editorial that took the initiative and started to collect library examples of "meeting the users with a digital information desk". During certain periods there were frequent article revisions with new content, several times a week. The news was often related to locally produced videos, social media texts, and new digital services (I1; Krämer 2020a; 2020c; 2020b). In connection to this, the editorial highlighted relevant courses linked to the local initiatives and also developed new ones inspired by them: for example, on how to livestream literature promotion activities and how to understand copyright (I1). The coronavirus outbreak thus stimulated more intensive interactions between the platform, its users and content producers.

On a more granular level it can be seen that the social production process is organised around, albeit not on, Digiteket. The course guide mentions that it is the editorial team's task "to edit every course before publishing in dialogue with you as course producer" (CG). The editorial team functions as a gatekeeper, and it is questionable whether a dialogue between equal actors exists. The guide stipulates that the platform user, implicitly an individual, needs to read the entire course guide, have advanced subject knowledge, and pass an advanced third level course on Digiteket in order to be "able to create and teach himself" (CG). Anna admits this "raises the threshold for sharing" (I1), but that this ideally will change over time (Anna I1; Erik I2).

Finally, the editorial team rarely outsources work to other writers (I2) as editors usually do. The team more closely resembles a producer of learning material (Erik I2), a kind of production agency. The editorial team plays a dominant role in the production of resources. The examples mentioned above concern articles, but the pattern is also obvious in relation to the courses. Table 2 covers the distribution of the main responsible course creators on Digiteket, and the editorial team produces 49 out of 76 courses as such. ${ }^{5}$ Regional librarians and public librarians play minor roles.

${ }^{5}$ Other people may have contributed to the courses, but they are not mentioned as copyright holders. 


\begin{tabular}{|l|l|l|l|l|l|l|}
\hline \multirow{2}{*}{} & \multicolumn{3}{|l|}{ Digiteket's five selected themes (from DigComp 2.0) for its courses } & \\
\cline { 2 - 7 } & $\begin{array}{l}\text { Information } \\
\text { \& Analysis: } \\
14 \text { courses }\end{array}$ & $\begin{array}{l}\text { Digital } \\
\text { collaboration: } \\
16 \text { courses }\end{array}$ & $\begin{array}{l}\text { Create } \\
\text { content: } \\
24 \text { courses }\end{array}$ & $\begin{array}{l}\text { Security: } \\
8 \text { courses }\end{array}$ & $\begin{array}{l}\text { Problem } \\
\text { solving: } \\
14 \\
\text { courses }\end{array}$ & $\begin{array}{l}\text { Total: } \\
76 \\
\text { courses }\end{array}$ \\
\hline Editorial team & 10 & 11 & 16 & 8 & 4 & 49 \\
\hline Researchers & 1 & - & - & - & - & 1 \\
\hline $\begin{array}{l}\text { Regional } \\
\text { librarians }\end{array}$ & 1 & 2 & $\begin{array}{l}3 \text { (one } \\
\text { resource is } \\
\text { co-created } \\
\text { with a } \\
\text { public } \\
\text { librarian) }\end{array}$ & - & 2 & 8 \\
\hline $\begin{array}{l}\text { Public } \\
\text { librarians }\end{array}$ & 2 & 1 & $\begin{array}{l}3 \text { (one } \\
\text { resource is } \\
\text { co-created } \\
\text { with a } \\
\text { regional } \\
\text { librarian) }\end{array}$ & - & - & 6 \\
\hline $\begin{array}{l}\text { Other } \\
\text { creators }\end{array}$ & - & $\begin{array}{l}3 \text { (Wikimedia } \\
\text { Sweden) }\end{array}$ & $\begin{array}{l}3 \text { Wikimedia } \\
\text { Sweden) }\end{array}$ & - & & \\
\hline
\end{tabular}

Table 3: Quantity of courses on Digiteket by creator category, February 25th, 2021 (Anna, 13 April 2021; Kungliga biblioteket 2021b; 2021a; 2021e; 2021d; 2021c). ${ }^{7}$ One course has main creators from two different creator categories.

The informants stress that it is difficult to organise the multi-actor production of learning resources in the library sector, especially in relation to collective on-platform work (I2). The New Public Management model, together with municipal self-government (Kommunala självstyret), makes the sharing of work processes on Digiteket difficult. There are many independent stakeholders with their own budgets and missions involved (Erik I2). Further, the stakeholders do not communicate in ideal ways (Anders I2). Introducing more collective production processes will require a strong mandate and project description, and firm steering (Anders I2). Erik adds the importance of finding ways to give economic value to librarians' active and productive participation on the platform during labour time. It is easy to see what is gained from Digiteket but harder to justify a staff member's use of two weeks for the project on the municipality's budget (Erik 12). ${ }^{8}$

The sharing paradox mentioned in Section 6.3 is valid also in relation to social production processes. Collaborative production and peer production work well in some specific contexts, such as Wikipedia or a specialised subject forum related to hobbies like fishery or Star Trek, for example: "If we are talking about enthusiasts like

${ }^{6}$ DigJourney is a commercial entity.

${ }^{7}$ Informant Anna helped with identifying course creators.

8 This point is confirmed by one of the regional librarians during the ending ceremony of the project (Svedgård Lindmark 2020b). 
Wikipedians, Star Trek fans or sport fisherman fans, then there exists a tradition of sharing" (Anders 12). These enthusiasts can be prolific producers of content for a platform in their leisure time (Erik 12). However, being a teacher or librarian is too broad a category for this logic to play out: as Anders states, "I do not feel that I have too much in common with all other teachers in Sweden" (I1). Furthermore, the professional character of Digiteket is problematic in relation to peer production. Formal professional activities focused on continuous education, connected to wage labour, are at some distance from ardent fan cultures (I2).

At the same time the article on sharification on Digiteket proposes that gamification could potentially generate voluntary peer producers or produsers that become so engaged and knowledgeable that they could be entrusted with more editing powers on the platform (Krämer 2020e). Erik contends that it would be possible to develop Digiteket in this direction, but that it would require a new governing model and better "possibilities for library people in Sweden to interact on the site"(I2). Anders, on the other hand, contends that voluntary work time on Digiteket needs to be paid in some form or other, for example, through unemployment benefits (I2). Erik states: "We have not solved this at all yet. It's like Michelangelo, we chip away [signals strokes with a chisel on an imaginary sculpture] at the Digiteket we would like to have in the future. It will probably be a very long project before we can get this to work" (I2).

\section{Analysis}

This section provides a deeper interpretative analysis of the thematised empirical findings presented in the previous section. The analysis broadly follows Table 2 and refers to the concepts of education, Bildung and gamification as presented in Section 4.

\subsection{Spectrum Between Horizontality and Hierarchy}

The initial rudimentary group function on Digiteket created a narrow kind of group sociality which allowed for the free creation of private groups. It came with a hierarchical feature distinguishing between invited and non-invited platform users. The private groups and the chat feature point - albeit weakly - towards a dialogical and deliberative direction of horizontal discussions, but the hierarchical feature points in the opposite direction.

The 2020 revision introduced public groups that were searchable and visible for all interested platform users. The default option was still private groups, but the horizontal character and the similarities with deliberative democracy were strengthened when private and indirectly hierarchical groups were challenged by a public option.

In the revision of Digiteket the user profile pages were gamified. Awards were given for specific achievements and were accompanied by slogans. One was "We like that you build team[s]". The 'We' refers to the editorial team. It speaks to all the users from a privileged position similar to the position of representatives vis-à-vis citizens. More hierarchical and limited forms of participatory democracy including grains of representative democracy also align with the slogan.

Looking at the platform's content, the guidelines see Digiteket as a professionally well-structured and assessed "knowledge bank". It is a standard for (in)forming and educating individuals in particular in standardised competences laid down by the EU. This leads to high thresholds for participating in the production and sharing of learning resources. None of the activities are unqualified: you cannot do and share exactly what you want on the platform. Ideally, this leads to low thresholds for participating as receiving and studying learners. 
The advocated "sharing culture" is mediated by this digital knowledge bank, and it is a hierarchically structured, interrupted form of sharing. The sender is a course producer professionally accepted by the editorial team, whereas the receiver is a more passive 'reader' of the resource. The sharing does not initiate dialogical deliberation, except vaguely and implicitly between students at the receiving end (contradicted by the group function's status). It is also focused on so-called spreadable media, rather than on working together and sharing work processes on the platform. It is this sharing - sometimes with gamification as a proxy - that is advocated and initiated by the editorial team and project members.

Finally, the platform is also presented as a guide to the digital jungle, and it talks to its subjects and teaches them, as shown in Section 6.2. The instrumental DigComp framework is embraced by the informants as part of a pedagogical effort labelled as continuous education. The concept connects to education and goal-oriented forms of Bildung. The fixed competences, added externally from the EU or in the name of global competitiveness, are for the individual learner to conquer and win. To Anna, this ongoing quest creates a motivation to learn.

These top-down views align well with the aim and processes of representative democracy and its highly regulated hierarchies, as well as with the instrumentality of education. It is hard to become a pedagogical producer, and hard to become a decisionmaking representative. The participants rarely take part in the teaching, just as the voter seldom takes part actively in the decision-making. Forms of participation are limited, predominantly confined to studying as an individual, in the same way that one votes alone. No real deliberation is supported between the sender and the receiver of learning resources. The focus is on the individual receiving education from professional educative sources, approved by professional decisions, much in the way that citizens' individual voting is based on political parties and representative-approved messages.

The statement that standardised goals for standardised competences creates an inner motivation to learn, together with a defence of the DigComp-derived framework, plays down possible problems with hierarchical and instrumental education, embracing the learning of competences that emanate from the needs of alien institutions. The creation of well-informed librarians is favoured, rather than the librarians' freer Bildung. This implicit reference to global competitiveness is, in its standardised and hierarchically imposed character, possibly linked to structural features of representative democracy. Indirectly, parliamentary democracy is the dominant democratic form of capitalism, and both are strongly tied to each other in liberal thought.

Digiteket's group function connects to limited forms of direct, participatory, and especially deliberative democracy within small private groups. This undercurrent contrasts with the overall project's hierarchical management, focused on individual students and instrumental education based on professionally standardised learning resources. The initial design decision, referred to above, to keep the group function simple - either because of a lack of trust in librarians' digital competences or out of administrative considerations regarding the development of the platform - points to the undercurrent's minor position.

Potentially, these top-down views could be applicable to a hierarchical and limited participatory democracy that embraces a very goal-oriented Bildung. But the emerging picture clearly speaks against more horizontal forms of participatory and deliberative democracy. 


\subsection{The Role of Professionality}

The guides see Digiteket as a professional, well-structured and well-assessed "knowledge bank", a standard used for (in)forming individual professionals. This leads to high thresholds for participation in the production of learning resources, and in that sense also for learning to be a pedagogue by doing or practice: by being part of the teaching. The concept of a knowledge bank translates quite literally to the banking concept that critical pedagogical theory and critical information literacy in the tradition of Paulo Freire are criticising for its alienated and fragmentised form (Downey 2016).

But the individual focus of the DigComp's framework used here is also criticised within DFUF. A more social perspective is needed within the educational framework as a complement to the individual focus. This social alternative is institutional and instrumental in character and expressed as organisational development in the library sector. Librarians should be pedagogically (in)formed so that they can respond to the sector's needs.

Digiteket's pedagogical effort is framed as part of a continuous education. The concept connects to both instrumental education and goal-oriented Bildung (as Bohlin (2018) describes); although it is predominantly fixed competences that are to be conquered. Anders relates these competences explicitly to global competitiveness.

The platform's feature as a guide and the editorial team 'talking to' its target group as a gatekeeper add to the two intertwined aspects of a professional and standardised knowledge bank, and a dominant instrumental and external (as regards individual students) education or non-free Bildung. The sharing on Digiteket is not unqualified. You cannot do and share exactly what you want. The shared resources have to fit the platform's aims and professional standards. This is a hierarchical regulation reminiscent of representative democracy's standardised demands on political parties and actors taking part in the public sphere.

The 'representative' of representative democracy is a professional with a distinguished position. The concept of 'profession' could be understood as acting out a function, or fencing in an expertise area in which professionals have a monopoly (Brante et al. 2009; Nolin 2008; Wisselgren 2018). Non-professionals, amateurs and students, or voters, are positioned outside the function or expertise area. Interestingly, it is precisely the professional librarians that are positioned on the outside in the empirical material of this study, being subject to sanctioned actions by the representatives of the editorial team. Participation is not horizontal between equals, but hierarchically structured.

These positions mainly connect to the aims and processes of representative democracy, where citizens ideally should be educationally well informed in the eyes of an external system that implicitly places demands on the individual (voter or librarian). Once again, a top-down view could potentially apply also to limited forms of hierarchical participatory democracy.

\subsection{Instrumental Personalisation}

The previously mentioned personalisation of profile pages obviously concerns individuals. The personalisation works within the DigComp framework, operationalised through the self-evaluation test for individual users: a standard for the individual to be measured against. This framework will potentially be complemented by themes related to organisation development, which would shape the character of personalisation on the platform. It is unclear from the material how these themes would be designed, or by whom. During DFUF's existence, it was the project members that took these decisions at a national level. 
The progression of being informed on Digiteket is visualised and gamified with personal metrics and statistics surrounding the self-evaluation on the site. "Can you manage to reach the top?", the award section asks, putting a strong educational or Bildung instrumentality in play. However, social ambitions also leave traces in the personalisation work. To promote the group function, as well as group creation, slogans like "Communicate more!" and "Work across borders!" are used on the personal profile pages. Personalisation can thus have deliberative and collaborative ends. And in this case, as has been mentioned (see Section 7.1), it is the editorial team that gives the advice.

The gamification strategy in the personalisation work is actively connected with sharing, sharification and the creation of a sharing culture on Digiteket, much in line with Web 2.0 ideology. Individualism should thus foster sociality in the sense of sharing resources on the platform. One informant thinks that the time is ripe for a deepened form of gamification on Digiteket, with the goal of getting users involved and learning at the same time.

Another angle of instrumental personalisation is expressed in the wish for the platforms' learners to practice self-study. This self-study is thought to be free in the absence of external parties' examination mechanisms, but one informant stresses that librarians have been mandated to do platform courses by their employers, while another hints that activities on the platform will be used by employers in their evaluation of their staff. Thus, even if the learners' inner drives are emphasised, the overall standardised instrumentality transforms them into directed inner drives, open for and actively engaged in others' standardised education. This can be understood as a slightly nonalienated education, or as an instrumental non-free Bildung.

The guidance regarding self-study is further centred on specific forms of deliberation organised by the courses' control questions. Together with standardised and professionally controlled learning resources, this introduces a hierarchical dimension in a discursive practice that otherwise connects to deliberative democracy.

The individualism in the above examples resembles the individualism of representative democracy. The shaping of the individual's inner drives to learn external categories, either from DigComp or from the profession, bear similarities to the shaping of voters' conditions with a political party system in representative democracy. Both kinds of external categories should ideally be (self-)studied by the individual learner or voter. They provide a standard to measure individual conceptions against - in internalised and externalised forms. Personalisation and gamification (even when it propagates sharification) are subordinated to this educational instrumentality of making the librarian or voter well-informed in accordance with externally set categories. The radical critique of gamification as detrimental for joyful play and, if stretched, voluntary and intrinsic Bildung processes, is not reflected in the material; rather, the opposite is true.

\subsection{The Character of Co-operation}

The structuration of Digiteket's articles and courses are derived from the EU's DigComp framework, which is focused on individuals' competences. Hierarchy, in combination with a traditional political institution as an origin, points toward the category of representative democracy, especially in relation to the processes and actors involved. One of the Digcomp framework's themes is 'digital collaboration', which could indicate an affinity with direct and participatory democracy; but this social track is minor in the overall picture. Digital collaboration is also understood as something other than producing content, which limits the intended level of participation. Producing together on the platform is not explicitly sought. 
Looking at the group function, the 2020 revision introduced the option of public groups that were searchable and visible for all interested platform users. Even if this broadened the platform's sociality, the group function still only consisted of a rudimentary chat. Despite this, the function leaned toward deliberative democracy, rather than toward direct and participatory democracy, since the function lacked common workspaces and uploading options that facilitated more embodied (albeit digital) cooperation.

Social cooperation related to the platform also takes the form of communication between the editorial team, regional and public librarians, and other actors, although this is a communication style where the editors are gatekeepers with high standards for the content in a way that differs from Web 2.0 discourse or peer production. In this process, the editorial team takes on the role of a production agency, a small, tight content producer group that initiates and collects information about news related to the local production of learning resources. The deliberation is not a dialogue between equals, and the communication has hierarchical features reminiscent of representative democracy's institutional top-down processes.

The statement that the group function was kept technologically simple because of a doubt of public librarians' digital competences, although downplayed by the project lead's emphasis on path dependencies and administrative concerns, implies high standards for collective forms of participation on the platform. Participation as in social interaction is often placed outside of the platform. The recommendation is for platformbased self-study of a type that would frequently herald a collegial discussion at the librarian's workplace. The social interaction is thus discursive and influenced by Digiteket's resources but placed within practical library operations in the workplace. At other times, socially produced material at the local or regional library level is aimed at the platform. From Digiteket's perspective, digital collaboration is thus not primarily about socially producing content on the platform but sharing it.

The sharing of approved and standardised learning resources on Digiteket is a limited form of participation, mediated by a digital platform perceived as a knowledge bank. It does not build on or build a connection between the sender and receiver. The sender is a professionally accepted course producer, and the receiver is a more passive reader of the resource. The two do not meet each other in the asynchronous interaction. Sharing in this form is not equivalent to the gift economy's creation of sociality. Lewis Hyde once talked about the gift that goes around, the act of gift-giving leading to the act of returning the gift, gradually expanding sociality (Hyde 2012). This logic characterised early peer production (Benkler 2006; Lund 2015b; 2017), but the Web 2.0 sharing industry transformed and reified the processes into a sharing of "spreadable media" on many different platforms (Jenkins et al. 2013; Lund and Zukerfeld 2020). The sharing concept is thus broadly ideological (Lund and Zukerfeld 2020; Miller 2011; Scholz 2016). This sharing is focused on product and commercial logics, rather than on social gift-giving. It is this sharing of professional and standardised content, albeit non-commercial content shared only on one platform, rather than the sharing of work processes (working together) that is referred to in the context of Digiteket. It is a sharing without sociality in a deeper sense. In the interviews, one informant does think that sharing is about learning and sharing between peers, but another sees it as helping other professionals, and yet another stresses that sharing helps education become more effective than before.

Sharing on the platform is top-down advocated and stimulated through Web 2.0 gamification techniques by the editorial team. Gamification uses both internal and external motivations, according to the informants, and is implicitly described as a tool to 
soften up instrumental education, making it more akin to goal-oriented Bildung. Moreover, the instrumental ends seem to vary: an intensified sharing of learning resources that facilitates learning together and helping each other to learn is something else than promoting more effective education.

Looked upon through the lenses of the study's democratic categories, Digiteket's sharing is highly regulated and hierarchical. It helps to (in)form individual public librarians through increased access to reified and professionally standardised learning resources, in much the same way that the regulated messages of a political party representative (in)forms the citizens in a representative democracy. The reward comprises librarian-learners' or voters' curated attention and engagement. From a social perspective, this is a limited form of participation. The focus is on well-informed rather than democratically active and participatory citizens involved in producing democratic decisions.

Deliberation on the platform is promoted discursively on it, but simultaneously counteracted by the platform's rudimentary group function. The guide recommendation instead places deliberation outside of the platform. And, finally, the communication between the editorial team and local and regional libraries is as hierarchical as the sharing. This ambiguous relation to a deliberation that is often externalised and hierarchically structured points to an intermixing of the categories of representative and deliberative democracy.

Certainly, there exists an undercurrent that points in the direction of deliberative and participatory democracy when sharing is discussed. Two editorial team members, Anders and Erik, go further in their thoughts on a deeper kind of sharing: the editorial team should as an ideal be abolished and a new peer-to-peer governance model could be implemented. This points to a bottom-up participatory democracy, or even to direct democracy, but this undercurrent is weak and explicitly utopian. The informants' discussion of sharing never entails the activity of working together. Instead it concerns sharing resources, and enthusiasts working voluntarily as individuals. And for now, Anders stresses, the editorial team is needed as a gatekeeper. Utopia is framed by the overall project's mission to make Sweden globally competitive in the digital field. To the extent that participatory and deliberative democracy is present in the material, it is infused and dominated by the logic of representative democracy.

\subsection{The Problematic Bildung and Sociality}

An external instrumentality in relation to the individual librarian, rooted in the EU or library sector, characterises both Digiteket's use of DigComp categories for individuals and the need for complementary organisational library development themes. The learner's own learning is not in focus. Librarians should be formed for the sector's needs in the same way that citizens should ideally be well-informed in representative democracy, for the democratic system's sake. The individual voting act is important only in relation to a bigger formal and institutional system, and an individual competence, as expressed in the material, is important in relation to an external instrumentality.

Implicitly, the learning - or, in a transferred meaning, the voting - only becomes problematic when it goes against the external systems' needs, as evidenced by the gatekeeping in accordance with externally set standards. Contradictions also surface in relation to self-study on the platform: is it seen as an examination-free activity or as an activity monitored by the employer? The standardised and monitored content on the platform, together with a monitoring library manager representing the sector, makes the individual learner's self-study mandated, and not so free. 
The hierarchical structuration and conception of this self-study is loosely connected at a structural level to the political representative's privileged position in making decisions. Free Bildung comes forward as a potentially problematic phenomenon, in much the same way as a bottom-up participatory democracy could be problematic within regulated and hierarchical representative democracy.

Regarding problematic sociality, the theme 'digital collaboration' is derived from DigComp, and it is a minor social track in Digiteket's setup. This is evidenced by the rudimentary group function both before and after the revision. Interestingly, the trope of the digital as a jungle, something wild, alien and perhaps intimidating, is addressed by the informants in relation to this group function. Within DFUF it is digitally mediated sociality in particular that is initially seen as problematic in relation to the user group, and by the software producer. This sociality seems to come with an accentuated technological complexity, regardless of new Web 2.0 technologies. On the other hand, this position is contradicted by conceptions of public librarians as social media savvy by two other informants, who stressed that they wanted a more developed group function from the outset, although this stance did not provoke a radical revision a year into the project. Instead, the question may be asked as to whether the participation of (prod)users is more of a problem for the service provider than for the intended user group. There is in any case a tension between the informants' and the project's view of the platform's social life.

DFUF's conceptions of the user group could be analysed in relation to the categories of democracy. In the first position, technology is a bit intimidating for the user group and the users need more technological formation to take a more active and collective part in the platform's life. This position connects to the idea that representative democracy builds on well-informed citizens. The second position, stressing that librarians are social media savvy, directly claims the existence of a technological competence, but the design of the platform does not reflect it, begging a deeper question of what this tells us about the project's democratic priorities in relation to deliberation and participation.

A specific kind of sharing culture is advocated and forms an important part of how sociality is understood. Despite this, sharing is perceived as hard to realise on the platform. The level of professional formality makes sharing problematic. The inner drive is hard to combine with professional interactions and serious continuous education especially as these connect to wage labour. Digiteket's activities are, according to one informant, far removed from the intensive Star Trek fan-production populated by intrinsically motivated produsers. The professional dynamic, the labour market's exploitative logic, and global competitiveness here inhibit the enthusiastic inner drives for voluntary and playful production.

This conflict can be explained by Lund's model for framing the concepts and relations between playing, working, gaming and labouring. On the one hand we have playing and working. In the former the goal is the activity itself; in the latter the production of useful values is important. On the other hand, we have gaming and labouring; both valorise results that can be measured and compared (Lund 2014; 2015a; 2017).

A tension exists in the empirical material between utopian hopes for collaborative production processes and more down-to-earth and critical views on the conditions for it. Two informants stress that deepened participation or peer production need financing in professional settings. This in turn activates another problem: the regional and municipal autonomy in Sweden and the New Public Management logic do not align well together in a national platform project. 
DFUF's relation to social participation on the platform is thus ambivalent. The platform prioritises a professional character that interferes with and prevents freer productive processes based on inner drives, freer Bildung processes, and the development of learning by doing. At the same time the "sharing culture" and "sharing thought" connected to digital Web 2.0 discourse is advocated in several and important ways, but always in a limited way more akin to hierarchical mediation (förmedling) focused on the distribution of professional learning resources, rather than on peer-to-peer sharing arising from freer learning-by-doing processes, which are hard to actualise and finance.

Thus, participatory and deliberative democratic processes, in the build-up of Digiteket, are either problematic because of their freer unstandardised bottom-up character, or in relation to the financing of the broadening participation of professional actors or representatives (in the transferred meaning) in the project. The practice of doing in common or commoning (De Angelis 2017) is absent in this pedagogical project, which in practice distances itself from freer collective Bildung processes.

\section{Discussion and Conclusion}

In this final section, having completed the interpretative analysis of the empirical findings, the analytical results are discussed and conclusions are drawn that answer the research questions.

First it can be concluded that the wider goals of DFUF and indirectly of Digiteket are set up by the Swedish government. The focus on global digital competitiveness and instrumental education was already set at the onset of the project, but the choice to let the EU's DigComp 2.0 provide a structural basis for the platform was not. However, David Lankes was invited to the inauguration of Digiteket as a "professor and library guru" (Kungliga biblioteket 2019). His stewardship model for librarianship sees the librarian in Web 2.0 terms, as a "facilitator of conversations", and emphasises librarians' horizontal knowledge construction and community-building together with the local community (Lankes 2015).

The project DFUF was thus from the start positioned between top-down demands for instrumental education and Web 2.0 desires regarding a deeper participation built on the affordances of digital technology.

The present study has identified an emerging pattern in relation to social and pedagogical themes that in turn can be connected to the question of which democratic vision the project encapsulates or expresses. ${ }^{9}$

A dominant trait has been identified in relation to the social interactions and pedagogical strategies addressed by the first research question. The main form of social interaction and pedagogical strategy favoured by Digiteket's developers is a hierarchical and instrumental education built on learning resources produced according to professional standards, coupled with ideas of librarians as traditional, relatively passive, predominantly individual students at the receiving end of Digiteket's mediation of hierarchically approved resources. From this perspective, librarians tend not to be viewed as peer producers that are learning by doing, producing articles and courses in more horizontal and communally set standards, for colleagues to use and tamper with.

This kind of instrumental education of professionals by pedagogical professionals who teach reified competences rather than dynamic competences including contextual

9 This pattern exists on an analytical level, as the informants' statements often contain a combination of the various positions. 
dynamics was termed outformation in 2003 by Cushla Kapitzke. Kapitzke contrasted outformation with empowering information. The latter involved problem-solving, emphasising processes inside people's heads, in combination with what she saw as the focus of contemporary information work on "[c]onnections rather than collections" with a critical eye on social and political ideologies (2003, 49; 53). From Kapitzke's perspective, inner drives of Bildung should be combined with a pedagogical emphasis on how literacies are produced, rather than on the fixed competences or products being produced. This focus on processual, cooperative, and communicative skills is also afforded by the low technological thresholds of new ICTs (Lund 2015b; 2017).

The question is, thus, whether or not the identified trait is equivalent to being at the forefront of digital development. The emphasis on learning resources comes closer to the focus of early DLs on the collections than to the social community building that marks the development of DLs since Web 2.0 technologies were introduced. The friction between a library and the Web 2.0 meme that Karen Calhoun (2014) pointed out in relation to $D L$ is still present in this study. Interestingly, though, the argument for avoiding Web 2.0 technologies because of their complexities turns the Web 2.0 meme against itself in its promotion of the traditional library meme.

The dominant pattern points to the category of representative democracy rather than the more horizontal and social forms of direct, participatory, or deliberative democracy. Hierarchies are built on gatekeepers who are also dominant initiative-takers in a way that resembles the role of political parties' representatives in representative democracy. There is little horizontal peer communication and no production of learning resources between librarian colleagues on the platform. Instead, the professional standard is set within DFUF by a mixture of regional and local librarians, together with teachers and pedagogues employed at the national and local levels.

Still - and this makes the answer to the first research question more nuanced there is a contrasting social and pedagogical undercurrent in the empirical material. DFUF uses personalisation, gamification, and avoids examination mechanisms, in order to stimulate goal-directed inner drives that connect to Bildung and collective forms of learning. The project also promotes sharification. However, this undercurrent is always confined within the general instrumental educational framework. Translated into democratic processes, this means that participatory and deliberative forms of democracy are treated as subordinated forms integrated into the representative democracy category.

Digiteket and DFUF have an ambiguous relation to deliberation, sharing and social production on the platform. Deliberation is promoted in words but is largely counteracted by the design of the platform, even if the option for public groups is a step towards more deliberation. Dialogue and horizontal deliberation predominantly exist at the learners' receiving end of the platform and are often relocated to external venues. Deliberation can also be limited in character and take the form of hierarchically structured communication between involved actors. As such, the position on deliberation points to an intermixing of the categories of representative and deliberative democracy, where the latter plays the subordinate part.

Digiteket's highly regulated and hierarchical sharing of learning resources, produced elsewhere and approved by gatekeepers, lacks a deeper sense of social dialogue in much the same way that regulated messages from political parties or representatives to citizens do. (In)forming individuals with shared learning resources into well-informed citizens is rewarded, rather than having citizens participate in the actual production of learning, or, in analogy, the democratic decisions. Reciprocal social production on the platform is scarcely present in the empirical material. 
Horizontal social production is not facilitated on the platform, but sharing material produced elsewhere on the platform is advocated. However, it is perceived to be problematic to initiate the sharing, either because the professional character interferes with the freer productive Bildung processes based on inner drives or because of the lack of economic funding.

Direct, participatory, and even deliberative democracy is thus designated as problematic even in the digital realm of a national digital platform.

Clay Shirky, in his book Here Comes Everybody: The Power of Organizing Without Organizations (2008), singles out four different levels of sociality in relation to the social web: sharing, co-operation, collaborative production, and collective action. Sharing constitutes a baseline, but often has the 'take it or leave it' character of the Web; cooperation is an offshoot of sharing and starts when we begin to interact and converse; collaboration involves collective decisions about collective projects; and collective action is about producing something together under a common governing regime (Shirky $2008,49-51$ ). Digiteket and its management remain predominantly in the first category, sharing, with some limited examples of the second and third categories of cooperation and collaboration. Pedagogically this means that learning subjects are often isolated individuals, or learners that interact on-platform with the help of a rudimentary group function, or off-platform. The platform's group members can, in limited ways, collaborate in attending and studying specific courses.

This, together with earlier analysis highlighting the relationship between social interactions facilitated by the platform and the project's democracy visions, allows us to answer the second research question. Digiteket's developers have favoured a dominant category of representative democracy that integrates and assimilates a subordinated undercurrent of deliberative and participatory democracy. Examples of direct democracy are only potentially found at the group level of the platform, but this feature has not been studied.

It is still early days for Digiteket, as several informants stress, but path dependencies are also being established. Calhoun views it as a failure when Web 2.0 rhetoric is used for promotion by DLs without meaningfully building social relations between its users $(2014,241)$.

The national digitalisation project's compound DL vision is, to sum up, positioned between a dominant traditional - hierarchical and instrumental - educational vision of professionally approved learning, and a contradictory social and pedagogical vision building on inner motivational drives and sharing. The latter undercurrent is limited in character within DFUF's vision, and it is subordinate to the overall instrumental and hierarchical framework. The project cherry-picks some features of Web 2.0 discourses and omits others that concern a deeper and more horizontal user and learner involvement - especially in relation to social production (i.e. peer production of learning resources). The contrast between the visions is not highlighted in the material or by the informants, but the implementation of the undercurrent is problematic, and perceived as such, within the dominant framework. This compound vision connects to representative democracy rather than to participatory and deliberative democracy. Pursuing the latter two forms in the future would require revisions of platform design, management forms, and financing models, involving committed actors at state, regional and municipal levels. 


\section{References}

Abbate, Janet. 1999. Inventing the Internet. Cambridge, MA: MIT Press.

Andersson, Jenny, Jacob Bäck and Therese Ernbrant. 2020. Svenskarna och Internet 2020. Stockholm: Internetstiftelsen.

Bibliotekslag. 2013. Accessed 27 September, 2021. https://www.riksdagen.se/sv/dokumentlagar/dokument/svensk-forfattningssamling/bibliotekslag-2013801 sfs-2013-801

Bearman, David. 2007. Digital Libraries. Annual Review of Information Science and Technology 41 (1): 223-272. https://doi.org/10.1002/aris.2007.1440410112

Bengtsson, Hans and Anna Melke. 2019. Vår Offentliga Förvaltning: Samverkan i Välfärdspolitiken. Malmö: Gleerups.

Benkler, Yochai. 2006. The Wealth of Networks: How Social Production Transforms Markets and Freedom. New Haven: Yale University Press.

Bishop, Ann P., Nancy A Van House and Barbara P Buttenfield. 2003. Digital Library Use: Social Practice in Design and Evaluation. Cambridge, MA: MIT Press.

Bohlin, Henrik. 2018. Medborgerlig Bildning: Om Varför Man Studerar på Högskola. Lund: Studentlitteratur.

Borgman, Christine L. 2000. From Gutenberg to the Global Information Infrastructure: Access to Information in the Networked World. Cambridge, MA: MIT Press.

Brante, Thomas, Jan Nolin, Harald Grimen, Björn Brorström, Staffan Lööf, Malin Sundström, Margareta Oudhuis, Peter Kammensjö, Håkan Torstensson, Birgit Wireklint Sundström, Catarina Eriksson, Maria Lindh and Lena Adamson. 2009. Profession och Vetenskap: Idéer och Strategier för ett Professionslärosäte. Borås: Högskolan i Borås. Accessed 3 May, 2021. http://urn.kb.se/resolve?urn=urn:nbn:se:hb:diva-4419

Castells, Manuel. 2001. The Internet Galaxy: Reflections on the Internet, Business, and Society. Oxford: Oxford University Press.

Calhoun, Karen. 2014. Exploring Digital Libraries: Foundations, Practice, Prospects. London: Facet.

De Angelis, Massimo. 2017. Omnia Sunt Communia: On the Commons and the Transformation to Postcapitalism. London: Zed Books.

Digiteket. 2020. Digiteket. Accessed 23 October, 2020. https://digiteket.us20.list-manage.com/subscribe?u=22c0f16bc5cd65b0a30775e63\&id=681b55a106

Downey, Annie. 2016. Critical Information Literacy: Foundations, Inspiration, and Ideas. Sacramento, CA: Library Juice Press.

Dryzek, John S. 2000. Deliberative Democracy and Beyond: Liberals, Critics, Contestations. Oxford: Oxford University Press.

European Commission. 2020. The Digital Economy and Society Index (DESI) [Text]. Shaping Europe's Digital Future - European Commission. Accessed 19 May, 2021. https://ec.europa.eu/digital-single-market/en/digital-economy-and-society-index-desi

FPFIS. 2016. DigComp 2.0: The Digital Competence Framework for Citizens. Update Phase 1: the Conceptual Reference Model. [Text]. EU Science Hub - European Commission, 1 June. Accessed 29 November 2020. https://ec.europa.eu/irc/en/publication/eur-scientificand-technical-research-reports/digcomp-20-digital-competence-framework-citizens-update-phase-1-conceptual-reference-model

Frenander, Anders. 2012. Statens Förhållande till Folkbiblioteken 1912-2012. In Styra eller Stödja? Svensk Folkbibliotekspolitik Under Hundra År, edited by Anders Frenander and Jenny Lindberg, 15-88. Borås: Valfrid. Accessed 20 April, 2021. http://urn.kb.se/resolve?urn=urn:nbn:se:hb:diva-3641

Grugel, Jean and Matthew L. Bishop. 2013. Democratization: A Critical Introduction. Basingstoke: Palgrave Macmillan.

Gutmann, Amy and Dennis F. Thompson. 2004. Why Deliberative Democracy? Princeton, NJ.: Princeton University Press.

Hansson, Sven Ove. 1992. Idéer om Demokrati (Vol. 5). Stockholm: Tiden.

Held, David. 2006. Models of Democracy. Stanford: Stanford University Press. 
Huotari, Kai and Juho Hamari. 2017. A definition for gamification: Anchoring gamification in the service marketing literature. Electronic Markets 27 (1): 21-31.

https://doi.org/10.1007/s12525-015-0212-z

Hyde, Lewis. 2012. The Gift. Edinburgh: Canongate.

Jenkins, Henry, Sam Ford and Joshua Green. 2013. Spreadable Media: Creating Value and Meaning in a Networked Culture. New York: New York University Press.

Jones, Elisabeth. 2017. The Public Library Movement, the Digital Library Movement, and the Large-Scale Digitization Initiative: Assumptions, Intentions, and the Role of the Public. Information \& Culture 52 (2): 229-263. https://doi.org/10.7560/IC52205

Kapitzke, Cushla. 2003. Information Literacy: A Postivist Epistemology and a Politics of Outformation. Educational Theory 53 (1): 37-53. https://doi.org/10.1111/j.17415446.2003.00037.x

Krämer, Christoffer. 2020a. Digital Folkbildning. Digiteket, 24 March. Accessed 20 October, 2020. https://digiteket.se/inspirationsartikel/digital-folkbildning/

Krämer, Christoffer. 2020b. Digitala Mötesplatser. Digiteket, 24 March. Accessed 20 October, 2020. https://digiteket.se/inspirationsartikel/digitala-motesplatser/

Krämer, Christoffer. 2020c. Digitalt Läsfrämjande. Digiteket, 24 March. Accessed 20 October, 2020. https://digiteket.se/inspirationsartikel/digitalt-lasframiande/

Krämer, Christoffer. 2020d. Digiteket Fräschar Upp! Digiteket, 31 August. Accessed 20 October, 2020. https://digiteket.se/inspirationsartikel/digitekeket-fraschar-upp/

Krämer, Christoffer. 2020e. Spelifiering eller Delifiering? Digiteket, 14 October. Accessed 20 October, 2020. https://digiteket.se/inspirationsartikel/spelifiering-eller-delifiering/

Kungliga biblioteket. 2021a. Digitalt Samarbete - Kurser. Digiteket. Accessed 5 February, 2021. https://digiteket.se/kurser/kompetensomrade/digitalt-samarbete/

Kungliga biblioteket. 2021b. Information \& Analys - Kurser. Digiteket. Accessed 5 February, 2021. https://digiteket.se/kurser/kompetensomrade/information-analys/

Kungliga biblioteket. 2021c. Problemlösning - Kurser. Digiteket. Accessed 5 February, 2021. https://digiteket.se/kurser/kompetensomrade/problemlosning/

Kungliga biblioteket. 2021d. Säkerhet - Kurser. Digiteket. Accessed 5 February, 2021. https://digiteket.se/kurser/kompetensomrade/sakerhet/

Kungliga biblioteket. 2021e. Skapa Innehåll - Kurser. Digiteket. Accessed 5 February, 2021. https://digiteket.se/kurser/kompetensomrade/skapa-innehall/

Kungliga biblioteket. 2020. Digiteket. Start - Digiteket. Accessed 29 December, 2020. https://digiteket.se/

Kungliga biblioteket. 2019. Digitekets Släppkonferens. Digiteket, 23 October. Accessed 23 February, 2021. https://digiteket.se/inspirationsartikel/digitekets-slappkonferns/

Lankes, R. David. 2015. The New Librarianship Field Guide. Cambridge, MA: The MIT Press.

Lave, Jean and Etienne Wenger. 1991. Situated learning: Legitimate peripheral participation. Cambridge: Cambridge University Press.

Lindberg, Jenny, Karen Nowé Hedvall and Malin Ögland. 2020. Folkbiblioteken och den Digitala Kompetensen: Uppdrag, Behov och Förutsättningar. Borås: Högskolan i Borås. Accessed 20 April, 2021. http://urn.kb.se/resolve?urn=urn:nbn:se:hb:diva-25197

Lund, Arwid. 2017. Wikipedia, Work and Capitalism: A Realm of Freedom? Cham: Palgrave Macmillan.

Lund, Arwid. 2015a. A Contribution to a Critique of the Concept Playbour. In Reconsidering Value and Labour in the Digital Age, edited by Christian Fuchs and Eran Fisher, 63-79. Basingstoke: Palgrave Macmillan.

Lund, Arwid. 2015b. Frihetens Rike: Wikipedianer om sin Praktik, sitt Produktionssätt och Kapitalismen [Dissertation], University of Uppsala. Hägersten: Tankekraft Förlag.

Lund, Arwid. 2014. Playing, Gaming, Working and Labouring: Framing the Concepts and Relations. tripleC: Communication, Capitalism \& Critique 12 (2): 735-801. 
Lund, Arwid. 2001. Albert Jensen och Revolutionen: Syndikalismens Revolutionära Idéer 1900-1950. Stockholm: Federativ.

Lund, Arwid and Mariano Zukerfeld. 2020. Corporate capitalism's use of openness: Profit for free? Basingstoke: Palgrave Macmillan.

Lynch, Clifford. A. 1993. Accessibility and Integrity of Networked Information Collections (Background Paper BP-TCT-109). Washington: Office of Technology Assessment.

Marczewski, Andrzej. 2017. The ethics of gamification. Crossroads (Association for Computing Machinery) 24 (1): 56-59. https://doi.org/10.1145/3123756

Miller, Vincent. 2011. Understanding Digital Culture. Los Angeles: SAGE.

Morschheuser, Benedikt, Juho Hamari and Alexander Maedche. 2019. Cooperation or competition - When do people contribute more? A field experiment on gamification of crowdsourcing. International Journal of Human-Computer Studies 127: 7-24. https://doi.org/10.1016/j.ijhcs.2018.10.001

Nolin, Jan. 2008. In Search of a New Theory of Professions. Borås: Högskolan i Borås. Accessed 3 May, 2021. http://urn.kb.se/resolve?urn=urn:nbn:se:hb:diva-4373

Olsson Dahlquist, Lisa. 2019. Folkbildning för Delaktighet: En Studie om Bibliotekets Demokratiska Uppdrag i en Digital Samtid. Lund: Lunds universitet, Institutionen för kulturvetenskaper.

Pateman, Carole. 2012. Participatory Democracy Revisited. Perspectives on Politics 10 (1): 7-19. https://doi.org/10.1017/S1537592711004877

Pateman, Carole. 1970. Participation and Democratic Theory. Cambridge: Cambridge University Press.

Uppdrag till Kungl Biblioteket om Digitalt Kompetenslyft, Ku2016/02084/KO; Ku2017/02646/KO 1. 2017. Accessed 11 November, 2020. https://www.kb.se/download/18.2705879d169b8ba882a62d6/1573651682197/1.1.5-2017-1025-1-Regeringsbeslut-uppdrag-digitalt-kompetenslyft.pdf

Regeringen, Stefan Löfven and Peter Eriksson. 2017. Hur Sverige Blir Bäst $i$ Världen på att Använda Digitaliseringens Möjligheter - en Skrivelse om Politikens Inriktning (Regeringens Skrivelse Skr. 2017/18:47; Regeringens Skrivelse). Regeringen.

Rivano Eckerdal, Johanna. 2014. MIK och medborgarskap. In Medie- och informationskunnighet $i$ en biblioteks- och informationsvetenskaplig belysning, edited by Olof Sundin and Johanna Rivano Eckerdal, 93-103. Stockholm: Svensk Biblioteksförening.

Scholz, Trebor. 2016. Platform Cooperativism: Challenging the Corporate Sharing Economy. Rosa Luxemburg Stiftung. Accessed 9 July, 2016. http://www.rosalux-nyc.org/wp-content/files $\mathrm{mf} / \mathrm{scholz}$ platformcooperativism 2016.pdf

Seaborn, Kate and Deborah I. Fels. 2015. Gamification in theory and action: A survey. International Journal of Human-Computer Studies 74: 14-31. https://doi.org/10.1016/j.ijhcs.2014.09.006

Shirky, Clay. 2008. Here Comes Everybody: The Power of Organizing Without Organizations. New York: Penguin Press.

Sundin, Olof and Johanna Rivano Eckerdal. 2014. Inledning: Från informationskompetens till medie- och informationskunnighet. In Medie- och informationskunnighet i en biblioteksoch informationsvetenskaplig belysning, edited by Olof Sundin and Johanna Rivano Eckerdal, 9-26. Stockholm: Svensk Biblioteksförening.

Svedgård Lindmark, Tomas. 2020a. \#digitalabiblioteket. Digiteket, 23 March. Accessed 20 October, 2020. https://digiteket.se/inspirationsartikel/digitalabiblioteket/

Svedgård Lindmark, Tomas. 2020b. Meeting_Saved_Chat Möte med Regionala Bibvht 201216 - Notepad.

Waters, Donald J. 1998. What are Digital Libraries? CLIR (Council on Library and Information Resources) Issues 4. https://www.clir.org/1998/07/clir-issues-number-4/

Wikipedia Contributors. 2021. Council Communism. In Wikipedia. Accessed 22 January, 2021. https://en. wikipedia.org/w/index.php?title=Council communism\&oldid=1001053410 
Wiktionary Contributors. 2019. Bildung. In Wiktionary: The Free Dictionary. Wikimedia Foundation. Accessed 26 February, 2021. https://en.wiktionary.org/w/index.php?title=Bildung\&oldid $=58178613$

Wisselgren, Per. 2018. Bibliotekarieutbildning och Bibliotekspraktik: En Professionshistorisk Triangulering. In Bibliotekarier i Teori och Praktik: Utbildningsperspektiv på en Unik Profession. Lund: BTJ Förlag.

Zichermann, Gabe and Christopher Cunningham. 2011. Gamification by Design: Implementing Game Mechanics in Web and Mobile Apps. Sebastopol, CA: O'Reilly Media.

\section{Appendix: Data Sources}

Anna. 2021, 22 February No Subject. E-mail.

Article Guide (AG). 2020, 4 February. Version 1.2 (Skapa artiklar till Digiteket).

Course Guide (CG). 2019, 11 November. Version 1.1 (Skapa pedagogiska kurser till Digiteket)

Erik and Anders. 2020, 13 November. Interview 2 (I2) [Zoom].

Karin and Anna. 2020, 30 November. Interview 3 (I3) [Zoom].

Karin and Anna. 2021, 25 January. Meeting [Zoom].

Karin and Anna. 2021, 8 February. Meeting [Zoom].

Karin and Anna. 2021, 13 April. Meeting [Zoom].

Karin, Lars and Erik. 2020, 19 November. Presentation (P) [Zoom].

Lars and Anna. 2020, 20 October. Interview 1 (I1) [Zoom].

\section{About the Authors}

\section{Arwid Lund}

Holds a PhD in Information Studies from Uppsala University. He is a Senior Lecturer and subject co-ordinator in Information Studies at Södertörn University, Sweden. He has published Wikipedia, Work and Capitalism: A Realm of Freedom? (Palgrave Macmillan, 2017) and Corporate Capitalism's Use of Openness: Profit for free? (Palgrave Macmillan, 2020, co-authored). He has also published articles and chapters on open data. You can contact him at arwid.lund@sh.se.

\section{Pamela Schultz Nybacka}

Holds a PhD in Business Administration from Stockholm University, Sweden. She is a Senior Lecturer at Södertörn University, and the founder and Head of their Librarianship programme. Her research topics include libraries and librarianship, books and readership, cultural economy and the arts in consumer culture. 